\title{
ANALISIS DAN PERANCANGAN SISTEM INFORMASI MANAJEMEN BERITA HASIL LIPUTAN WARTAWAN
}

\author{
Nori Sahrun \\ Sekolah Tinggi Ilmu Ekonomi Riau \\ Jl. HR. Soebrantas Kota Pekanbaru, Indonesia \\ Email : norisahrun84@gmail.com
}

\begin{abstract}
With the development of increasingly sophisticated communication technology today. In the media of data communication that is needed right now is communication in the form of sending text messages, images, sound and video in real time. Basically a web-based service is the best solution to support the performance of journalists in managing news more updates and completing news in accordance with the journalistic code of ethics in avoiding Hoaxs news. Thus, every reporter whenever and wherever he is can send news data by accessing the website through a smartphone. Information in the form of news is something that is really needed by the community, an information that is presented as more accurate, good news so as to prioritize the truth so that it is more up to date. To get news, there are many tools that we can meet, including print and electronic media which are interesting to read. However, information seekers have limited space to move because they have to return to the workroom in preparing the news they want to present. So that many events and events are missed in this condition. The establishment of this information system provides a space for news seekers, especially journalists, to look for more accountable and more complete news and more news that will be obtained by news seekers. In presenting news, it is certainly more creative and logical.
\end{abstract}

Keywords - Information System, News, Journalists, Website, Smartphone

Abstrak - Dengan berkembangnya teknologi komunikasi yang semakin canggih saat ini. Dalam media komunikasi data yang sangat dibutuhkan saat ini adalah komunikasi berupa layanan pengiriman pesan teks, gambar, suara maupun video secara real time. Pada dasarnya layanan berbasis web merupakna solusi terbaik untuk menunjang kinerja wartawan dalam mengelola berita lebih update dan melengkapi berita sesuai dengan kode etik jurnalistik dalam menghidari berita Hoaxs. Dengan demikian setiap wartawan kapan dan dimanapun berada dapat melakukan pengiriman data-data berita dengan mengakses website melalui smartphone. Informasi adalam bentuk berita merupakan hal yang sangatlah dibutuhkan masyarakat, suatu informasi yang disajikan sebagai berita yang lebih akurat baik sehingga mengedepankan kebenaran sehingga lebih up to date. Untuk mendapatkan berita sangatlah banyak sarana yang dapat kita temui diantarnyabaik media cetak maupun media elektronik yang menarik minat membaca. Akan tetapi, pencari informasi tebatas ruang geraknya karena harus kembali keruang kerja dalam penyusunan berita yang ingin disajikan . Sehingga banyak peristiwa dan kejadian yang terlewatkan dalam kondisi tersbut. Dengan dibuatnya system informasi ini sangat memberikan ruang gerak para pencari berita terutama wartawan dalam mencari berita yang lebih akuntabel dan lebih lengkap serta lebih banyak berita yang akan didapatkan oleh pencari berita. Dalam penyajian berita tentunya lebih kreatif dan logis.

Kata kunci - Sistem Informasi, Berita, wartawan, Website,Smartphone

\section{PENDAHULUAN}

Teknologi informasi saat ini sangat mengedepankan cepat dan akurat dalam penyajiannya.berbagai aspek sangat membutuhkan teknologi informasi sehingga memberikan kemudahan baik dalam penggunaan maupun pengelolaan. Pada umumnya pengolahan informasi dalam sebuah perusahaan sudah menjadi kewajiban selain sebagai promosi juda sebagai manajemen operasional lebih tersusun dengan rapi. Proses manual, dinilai tidak efektif dan efisien karena dapat menyebabkan pemborosan dari segi waktu ataupun biaya, seperti halnya yang terjadi dalam sistem informasi manajemen berita hasil liputan wartawan.

Proses sistem informasi manajemen berita yang masih menggunakan bantuan media lain seperti email dinilai belum maksimal, karena wartawan tidak dapat menambah mengedit dan menghapus berita secara langsung. Kelemahan lain dari proses sistem informasi manajemen berita tersebut yaitu tidak dapat membagi hak akses sesuai dengan keinginan, karena sistem hak 
akses pada email sudah ditetapkan oleh penyedia layanan email. Selain Itu, setiap data berita yang masuk juga berhak di akses oleh penyedia layanan email, sehingga menyebabkan kurangnya privasi yang dimiliki oleh wartawan.

Melihat berbagai kelemahan yang ada, maka sebuah sistem informasi sistem informasi manajemen berita hasil liputan wartawan diperlukan untuk mengatasi permasalahan tersebut. Sebuah sistem yang diusulkan harus mampu memberikan hak privasi dimiliki oleh wartawan. Selain itu sistem juga harus dapat memberikan hak akses terhadap seluruh pihak yang terkait, sehingga wartawan dapat menambah, mengedit, dan menghapus berita secara langsung.

A. Landasan Teori

Landasan teori digunakan penulis untuk mempelajari dan memahami teori-teori yang menjadi pedoman yang diperoleh dari berbagai buku, jurnal dan juga internet yang melengkapi konsep dan teori, sehingga relevan dengan masalah yang diteliti.

Adapun landasan teori yag digunakan adalah sebagai berikut :

a. Analisis Sistem

Analisis Sistem yakni penghubung utama antara kelompok sistem informasi dan seluruh organisasi.[1]

b. Perancangan Sistem

Perancangan sistem adalah Detail bagaimana sistem akan memenuhi kebutuhan informasi sebagaimana ditentukan oleh analisis system[2]

c. Sistem Informasi Manajemen

Sistem Informasi Manajemen adalah kumpulan dari sub- sub system yang saling terintegrasi dan berkolaborasi untuk membantu manajemen dalam menyelesaikan masalah dan memberikan informasi yang berkualitas kepada manajemen dengan cara mengolah data menggunakan komputer sehingga bernilai tambah dan bermanfaat.[4]

d. Berita

Informasi atau berita dewasa ini merupakan hal yang sangatlah penting, dimanapun dan kapanpun setiap orang pasti akan memerlukan suatu informasi baik itu informasi dalam bentuk berita ataupun informasi-informasi lainnya.[3]

e. Liputan media

Liputan media yakni jumlah orang yang memperhatikan peristiwa /issue, jumlah liputan media ini dipengaruhi oleh tanggapan publik, liputan koran tentang suatu isu saling mempengaruhi satu sama lain. [6]

f. Wartawan
Wartawan adalah sekolompok warga Negera yang menjalankan profesinya memenuhi hak asasi masyarakat berekspresi dan memperoleh informasi untuk mengembangkan diri dan lingkungan sosialnya sebagaimana di jamin oleh Pasal $28 \mathrm{~F}$ UUD 1945. [1]

\section{METODOLOGI PENELITIAN}

\section{A. Analisa Sistem}

Analisa sistem digunakan untuk mengidentifikasi dan mengevaluasi berbagai kekurangan serta kelebihan yang terdapat pada sistem yang sudah dimiliki. Adapun penjabaran dari analisa sistem yang ada saat ini adalah sebagai berikut.

\section{B. Analisa Sistem Yang Sedang Berjalan}

Sebelum melakukan pengembangan terhadap sistem yang sudah ada, maka diperlukan sebuah penelitian untuk memahami cara kerja dan melihat kekurangan pada sistem sistem yang sudah ada. Adapun gambaran dari analisa sistem yang sedang berjalan adalah sebagai berikut:

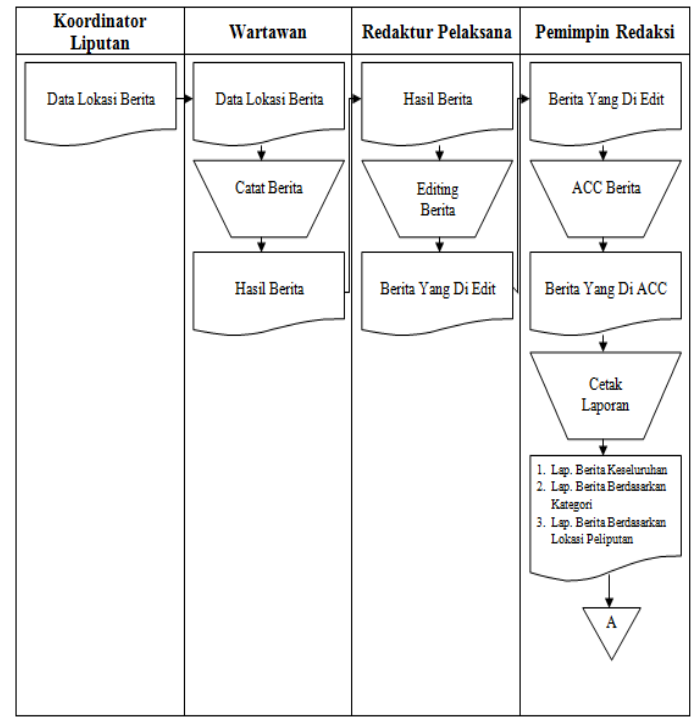

Gambar 1 Aliran Sistem Berjalan 
Berdasarkan aliran sistem informasi yang sedang berjalan, dapat diketahui bahwa sistem sistem informasi manajemen berita hasil liputan yang terdapat saat ini mayoritas masih berjalan secara manual. Berikut merupakan penjelasan dari gambar aliran sistem informasi yang sedang berjalan pada beberapa media.

1. Koordinator Liputan memberikan lokasi berita yang akan di liput kepada wartawan.

2. Kemudian wartawan melakukan peliputan berita berdasarkan data yang di berikan oleh koordinator liputan dan mencatat hasil peliputan dalam bentuk berita.

3. Berita yang telah di catat kemudian di serahkan kepada redaktur pelaksana untuk dilakukan proses editing.

4. Setelah proses editing berita selesai kemudian berita tersebut di berikan kepada pemimpin redaksi untuk dapat di lihat dan kemudian di acc.

5. Setelah berita di acc oleh pemimpin redaksi kemudian berita baru dapat di cetak menjadi bentuk laporan.

Berdasarkan penjelasan dari sistem yang telah berjalan, dapat di analisa beberapa permasalahan yang ada pada sistem tersebut. Permasalahan tersebut antara lain sebagai berikut:

1. Sulitnya wartawan dalam mengedit ataupun menambah berita jika terjadi kesalahan atau kekurangan data.

2. Proses sistem informasi manajemen berita hasil liputan menjadi lambat karena masih menggunakan cara manual, sehingga menyebabkan berita yang akan di tampilkan menjadi lambat.

3. Proses pencarian berita juga lebih sedikit sehingga mengurangi produktifitas wartawan dalam memberikan berita yang akurat, tajam dan terpercaya.

\section{Analisa Sistem Yang Diusulkan}

Berdasarkan analisa sistem yang sedang berjalan, maka dilakukan analisa sistem yang akan diusulkan untuk mengevaluasi beberapa kekurangan yang ada pada sistem yang berjalan. Adapun gambaran dari sistem yang diusulkan dapat digambarkan sebagai berikut:

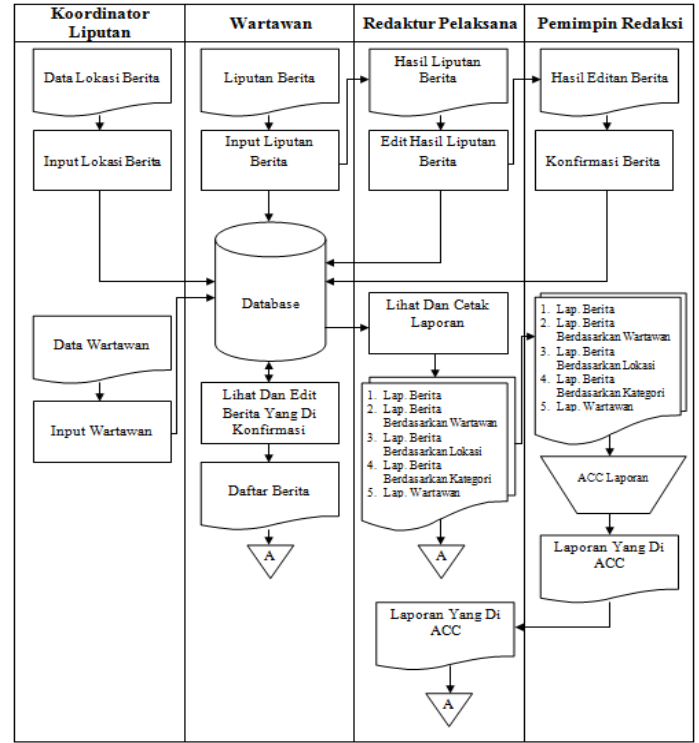

Gambar 2 Aliran Sistem Yang Diusulkan

Gambar di atas merupakan gambaran dari sistem yang akan di usulkan untuk mengatasi kekurangan pada sistem yang ada sebelumnya. Berikut penjelasan dari sistem informasi manejemen berita hasil liputan yang akan di usulkan.

1. Koordinator berita menginputkan lokasi peliputan wartawan ke dalam sistem yang akan di bangun.

2. Wartawan melihat lokasi peliputan ke dalam sistem dan melakukan peliputan berita. Kemudian berita yang di liput di catat dan di inputkan ke dalam sistem.

3. Setelah itu, redaktur pelaksana hanya tinggal masuk ke dalam sistem dan melakukan proses editing terhadap berita yang ada.

4. Proses selanjutnya, pemimpin redaksi melakukan pengecekan terhadap berita yang telah melalui proses editing. Kemudian setelah itu, pemimpin redaksi melakukan acc terhadap berita yang layak untuk di tampilkan dan memberikan berita tersebut kepada redaksi pelaksana.

5. Setelah seluruh proses selesai, kemudian wartawan dapat melihat berita yang telah di tampilkan dan melakukan proses editing apabila terdapat kesalahan.

Berdasarkan penjelasan tersebut dapat di analisa kelebihan dari sistem yang baru. Adapun beberapa kelebihan tersebut adalah sebagai berikut: 
1. Proses system informasi manajemen berita hasil liputan wartawan berjalan lebih cepat, karena telah menggunakan sistem sepenuhnya.

2. Wartawan dapat melakukan proses editing langsung terhadap berita yang telah di acc apabila terdapat kesalahan.

3. Masing-masing user memiliki hak akses tersendiri untuk menjaga privasi lebih baik.

4. Laporan yang akan di hasilkan lebih cepat dan lebih terinci dari sistem yang sebelumnya.

\section{Perancangan Global}

Perancangan global merupakan sebuah Perancangan yang menggambarkan sistem secara menyeluruh. Pada tahap Perancangan global akan digambarkan dengan diagram diantaranya : Context Diagram, Data Flow Diagram, dan Entity Relationship Diagram.

\section{E. Context Diagram}

Context Diagram merupakan Perancangan yang menggambarkan sistem secara umum. Penggambaran Context Diagram pada umumnya menggunakan 3 buah simbol, yaitu simbol persegi yang menggambarkan seorang user yang terlibat dalam sistem, simbol lingkaran yang menggambarkan suatu proses secara menyeluruh, dan anak panah yang menggambarkan aliran data. Adapun gambaran mengenai Context Diagram sistem informasi manajemen berita adalah sebagai berikut:

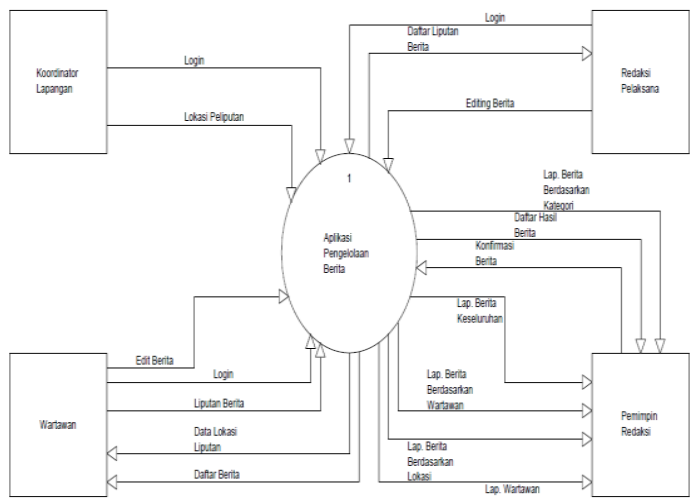

Gambar 3 Context Diagram

Berdasarkan gambaran yang ada pada diagram di atas, dapat di ketahui bahwa sistem informasi manajemen berita memiliki 4 user interface. Seluruh user yang ada akan terlibat ke dalam sistem dan harus menjalankan sistem yang akan di bangun.

\section{F. Data Flow Diagram}

Data Flow Diagram yakni gambaran terinci sistem yang disusun berdasarkan Context Diagram dan dibuat secara lebih rinci jika dibandingkan dengan Contet Diagram. Adapun gambaran dari Data Flow Diagram pada sistem sistem informasi manajemen berita adalah sebagai berikut:

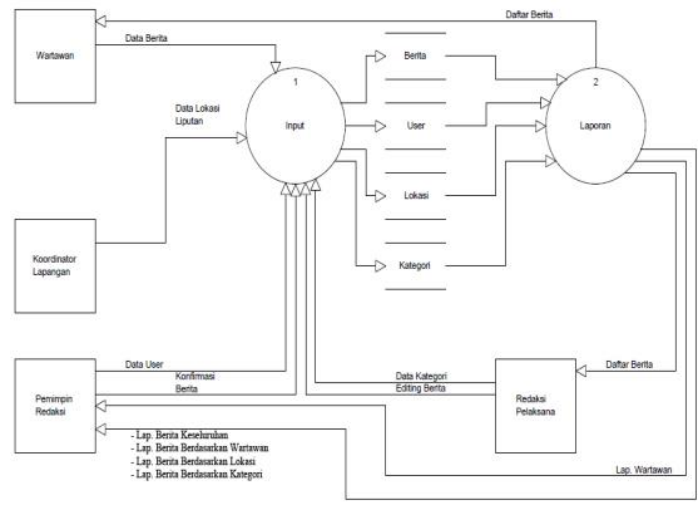

Gambar 4 Data Flow Diagram

Pada gambar Data Flow Diagram tersebut, dapat di lihat proses yang lebih rinci jika di bandingkan dengan Context Diagram. Pada diagram ini setiap proses baik itu input ataupun output di bangun secara terpisah.

\section{G. Entity Relationship Diagram}

Diagram ini untuk mengetahui hubungan antara masingmasing data pada sistem sistem informasi manajemen berita. Perancangan Entity Relationship Diagram di buat berdasarkan gambar yang terdapat pada Data Flow Diagram.

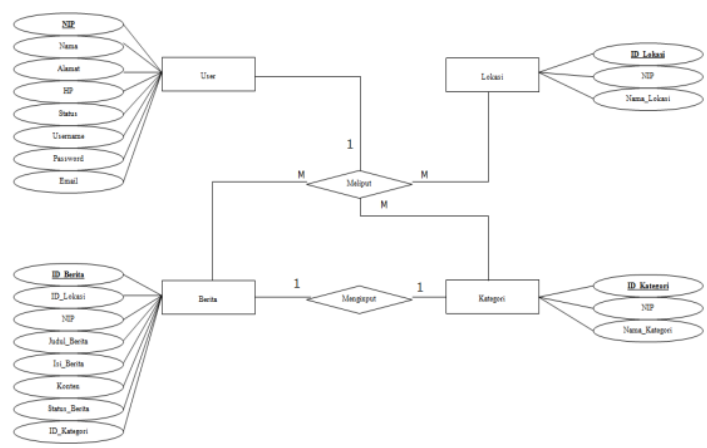

Gambar 5 Entity Relationship Diagram 
Diagram 5 menggambarkan suatu bentuk relasi antara setiap tabel yang akan digunakan dalam sistem sistem informasi manajemen berita.

\section{H. Perancangan Terinci}

Perancangan terinci yakni Perancangan yang menggambarkan perancangan sistem secara lebih rinci. Pada tahapan ini akan terlihat bentuk interface yang akan dirancang pada sistem sistem informasi manajemen berita. Adapun tahapan yang terdapat pada Perancangan terinci terdiri dari Perancangan Output, Perancangan Input, serta Perancangan Database.

\section{Perancangan Output}

Perancangan output merupakan sebuah Perancangan interface yang menggambarkan keluaran dari sistem yang akan di bangun. Berikut merupakan Perancangan output.

1. Laporan Wartawan
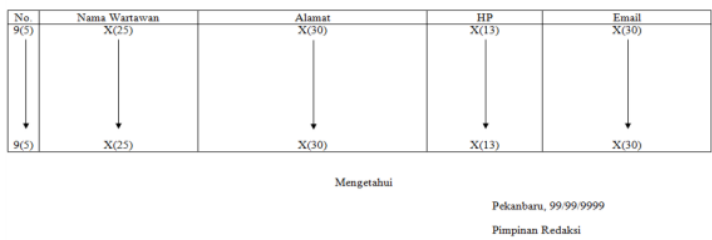

Gambar 6 Laporan Wartawan

Laporan wartawan digunakan menginformasikan seluruh wartawan dalam suatu organisasi. Laporan wartawan diperoleh dari data user yang memiliki status sebagai wartawan.

2. Laporan Berita Keseluruhan

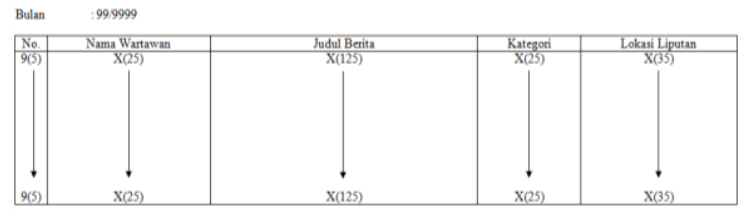

\section{Pekanbaru, 99.999999}

Pimpinan Redaksi

Gambar 7 Laporan Berita Keseluruhan

Laporan berita keseluruhan akan digunakan untuk menginformasikan seluruh berita.

3. Laporan Berita Berdasarkan Wartawan
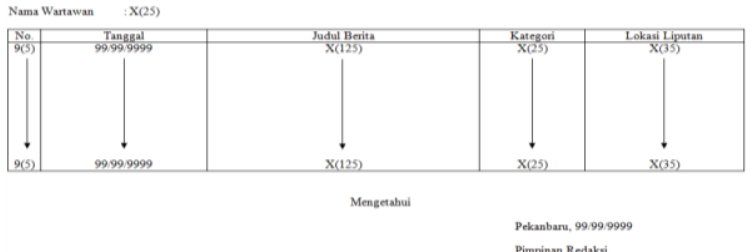

Pimpinan Redaksi

Gambar 8 Laporan Berita Berdasarkan Wartawan

Laporan berita ini akan digunakan untuk melakukan konfirmasi terhadap berita yang telah di masukkan oleh wartawan.

4. Laporan Berita Berdasarkan Lokasi

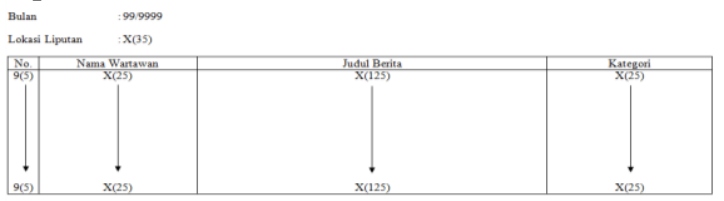

Peckanbanu, 99.999999
Pimpinan Reduksi

Gambar 9 Laporan Berita Berdasarkan Lokasi

Laporan tersebut akan digunakan untuk menginformasikan lokasi berita yang telah diliput.

5. Laporan Berita Berdasarkan Kategori

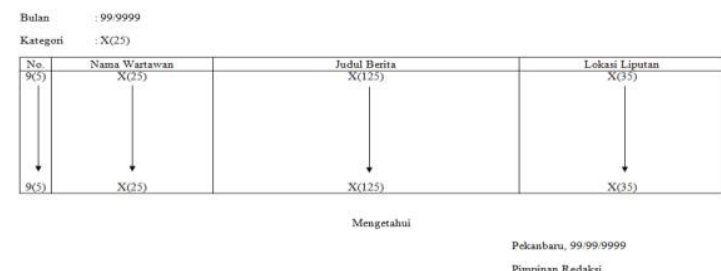

Gambar 10 Laporan Berita Berdasarkan Kategori

Laporan tersebut digunakan untuk membagi beberapa berita hasil liputan wartawan ke dalam berbagai kategori.

J. Perancangan Input

Perancangan input merupakan sebuah Perancangan interface yang menggambarkan masukan dari sistem yang akan di bangun. Berikut merupakan Perancangan input.

\section{Form User}




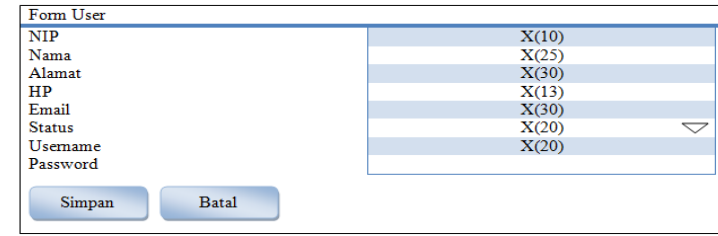

Gambar 11 Form User

2. Form Berita

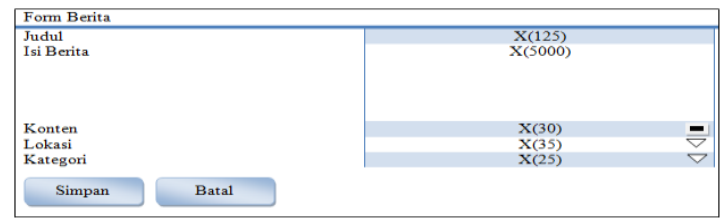

\section{Gambar 12 Form Berita}

3. Form Lokasi

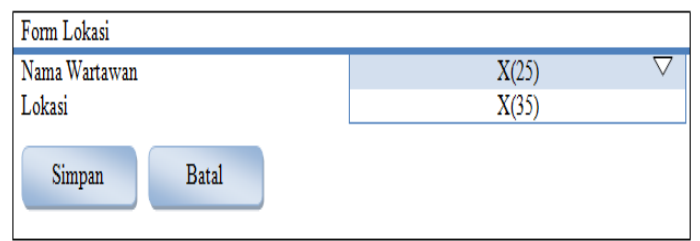

Gambar 13 Form Lokasi

4. Form Kategori

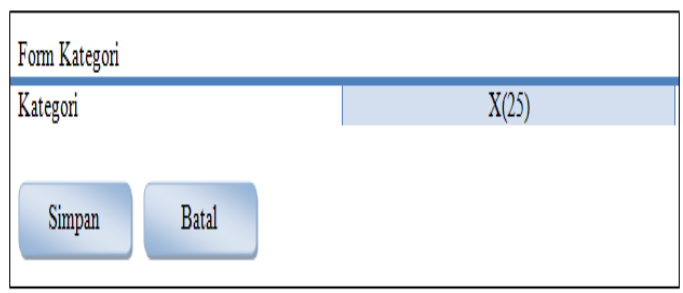

Gambar 14 Form Kategori
5. Form Login

\begin{tabular}{|l|l|}
\hline Form Login & \\
\hline Usemame & $\mathrm{X}(20)$ \\
Password & $\mathrm{X}(20)$ \\
\hline Login & \\
\hline & \\
\hline
\end{tabular}

Gambar 15 Form Login

K. Perancangan Database

Perancangan database merupakan sebuah Perancangan yang menggambarkan suatu media penyimpanan dari sistem yang akan di bangun. Berikut merupakan Perancangan database.

1. Tabel 3.1 User

Nama Database : pengelolaan

Nama Tabel : User

Primary Key : NIP

\begin{tabular}{|l|l|l|l|}
\hline \multicolumn{1}{|c|}{ Field } & Type & Size & \multicolumn{1}{c|}{ Description } \\
\hline NIP & Char & 10 & No. Induk Pegawai \\
\hline Nama & Varchar & 25 & Nama Pegawai \\
\hline Alamat & Varchar & 30 & Alamat \\
\hline HP & Varchar & 13 & No. HP \\
\hline Status & Varchar & 20 & Status \\
\hline Email & Varchar & 30 & Email \\
\hline Username & Varchar & 10 & Username \\
\hline Password & Varchar & 10 & Password \\
\hline
\end{tabular}

\section{Tabel 3.2 Berita}

Nama Database : pengelolaan

Nama Tabel : Berita

Primary Key : ID_Berita

\begin{tabular}{|l|c|c|l|}
\hline \multicolumn{1}{|c|}{ Field } & Type & Size & \multicolumn{1}{c|}{ Description } \\
\hline ID_Berita & Integer & 10 & Primary Key \\
\hline ID_Lokasi & Integer & 10 & Foreign Key \\
\hline NIP & Varchar & 10 & Foreign Key \\
\hline ID_Kategori & Integer & 10 & Foreign Key \\
\hline Judul_Berita & Text & 125 & Judul Berita \\
\hline Isi_Berita & Text & 5000 & Isi Berita \\
\hline Konten & Text & 30 & Gambar \\
\hline Status_Berita & Varchar & 20 & Status Berita \\
\hline Tanggal & Date & 10 & Tanggal \\
\hline
\end{tabular}

3. Tabel 3.3 Kategori

Nama Database : pengelolaan

Nama Tabel : Kategori

Primary Key : ID_Kategori

\begin{tabular}{|c|c|c|c|}
\hline Field & Type & Size & Description \\
\hline ID_Kategori & Integer & 10 & Primary Key \\
\hline Nama_Kategori & Varchar & 20 & Nama Kategori \\
\hline
\end{tabular}


4. Tabel 3.4 Lokasi

Nama Database : pengelolaan

Nama Tabel : Lokasi

Primary Key : ID_Lokasi

\begin{tabular}{|l|c|c|l|}
\hline \multicolumn{1}{|c|}{ Field } & Type & Size & Description \\
\hline ID_Lokasi & Integer & 10 & Primary Key \\
\hline NIP & Char & 10 & Foreign Key \\
\hline Nama_Lokasi & Varchar & 30 & Nama Lokasi \\
\hline
\end{tabular}

\section{HASIL DAN PEMBAHASAN}

A. User Interface

1. Halaman Login

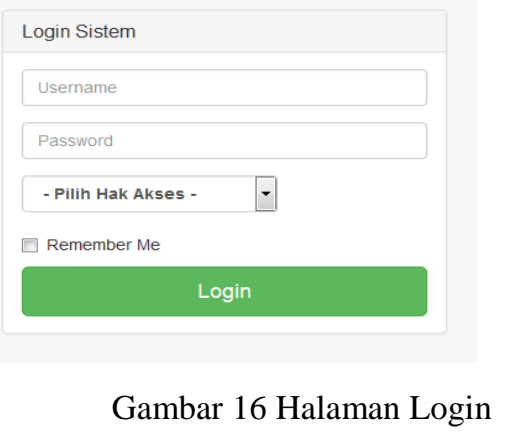

2. Halaman Utama

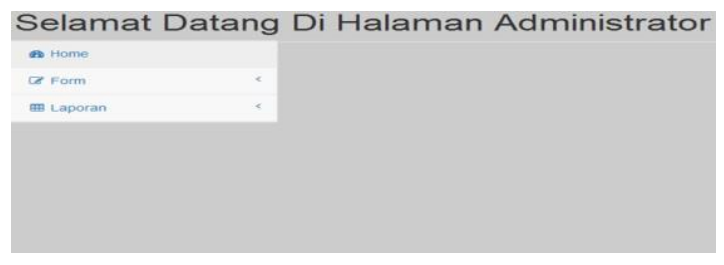

Gambar 17 Halaman Utama

3. Form User

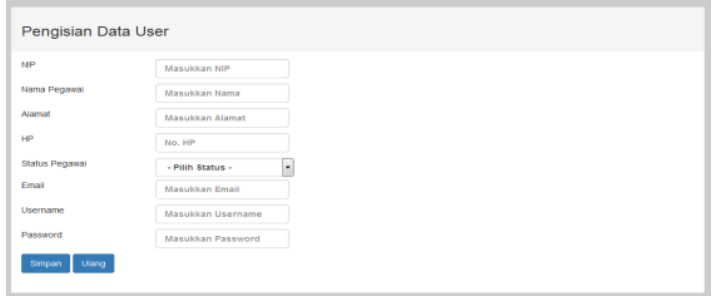

Gambar 18 Form User
4. Form Lokasi

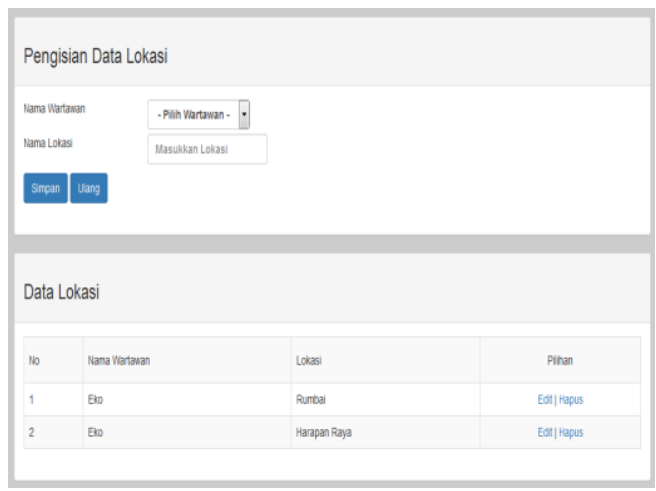

Gambar 19 Form Lokasi

5. Form Kategori

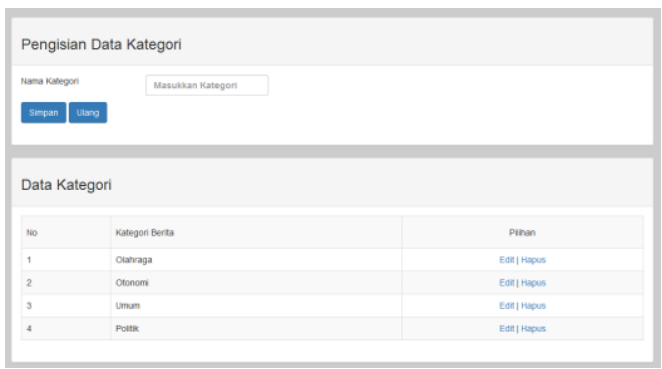

Gambar 20 Form Kategori

6. Form Berita

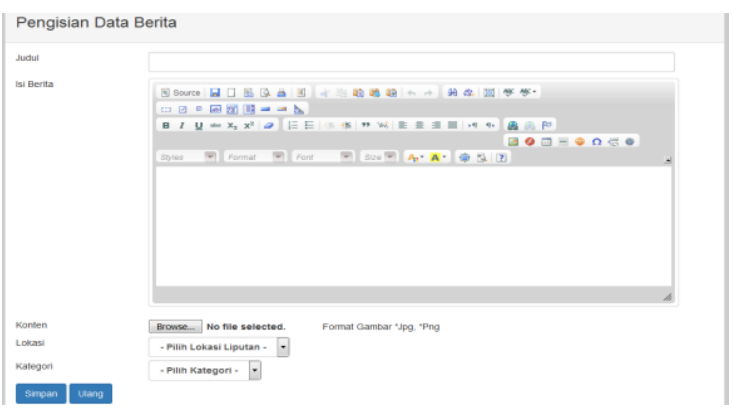

Gambar 21 Form Berita 
7. Laporan Wartawan

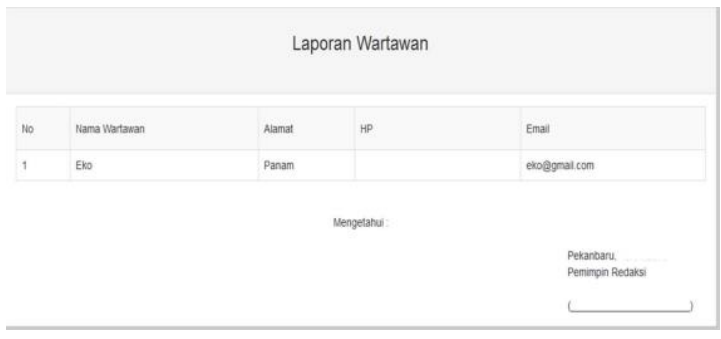

Gambar 22 Laporan Wartawan

8. Laporan Berita Keseluruhan

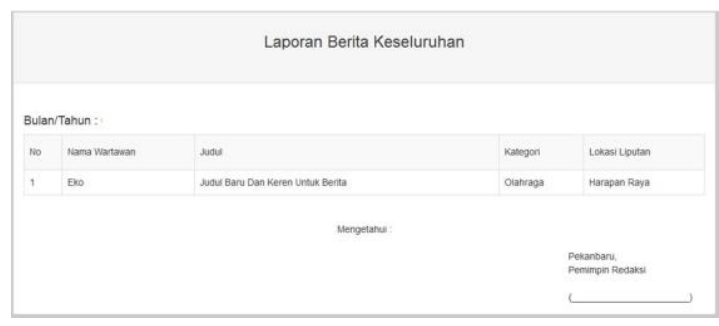

Gambar 23 Laporan Berita Keseluruhan

9. Laporan Berita Berdasarkan Wartawan

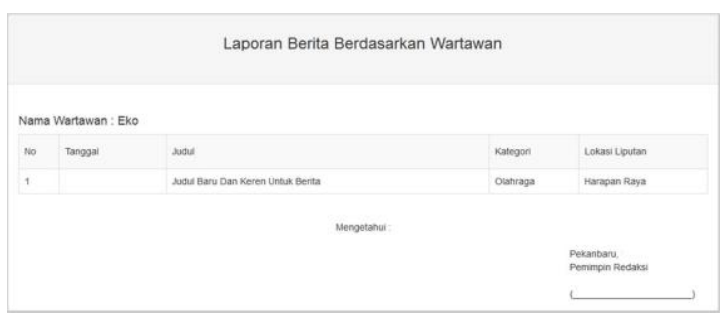

Gambar 24 Laporan Berita Berdasarkan Wartawan

10. Laporan Berita Berdasarkan Lokasi

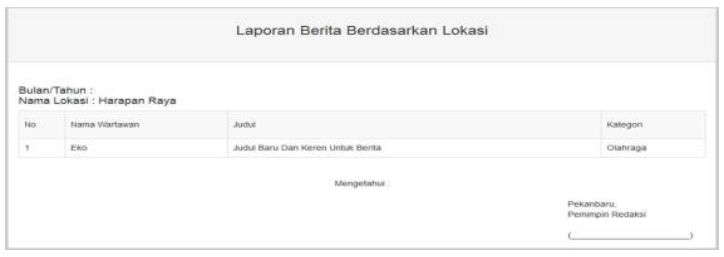

Gambar 25 Laporan Berita Berdasarkan Lokasi
11. Laporan Berita Berdasarkan Kategori

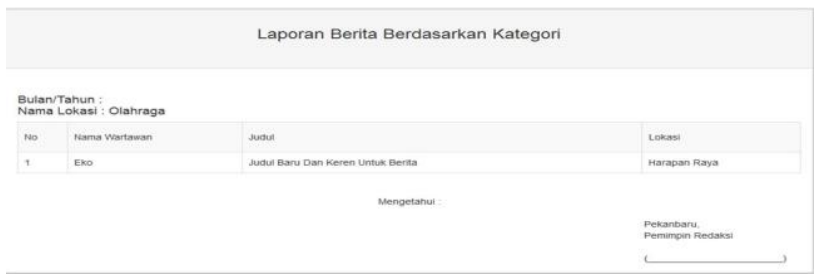

Gambar 26 Laporan Berita Berdasarkan Kategori

\section{KESIMPULAN}

Setelah melakukan implementasi sistem informasi manajemen berita hasil liputan wartawan, diperoleh beberapa kesimpulan sebagai berikut:

1. Dengan adanya sistem yang dibangun dapat mempermudah wartawan dalam mengedit ataupun menambah berita jika terjadi kesalahan.

2. Hak akses dalam proses pengelolaan berita hasil liputan dapat dibagi sesuai kebutuhan.

3. Menambah privasi yang dimiliki oleh wartawan.

4. Mempermudah proses pengelolaan berita mulai dari peliputan, editing, sampai proses konfirmasi berita sehingga berita siap di sajikan untuk masyarakat.

\section{DAFTAR PUSTAKA}

[1] Basuki, Murya Arief, (2009), Analisa Website Universitas Maria Kudus, Universitas Maria Kudus.

[2] Jogianto, (2003), Sistem Teknologi Informasi, Andi, Yogyakarta.

[3] Malang, Harijanto, (2014), Perlindungan Hukum Terhadap Wartawan Dalam Peliputan Berita-Berita Pemerintahan Dan Masyarakat, Universitas Sam Ratulangi, Manado.

[4] Nori Sahrun, (2018), Sistem Informasi Manajemen Aset Perusahaan Listrik Negara (PLN) Berbasis Web Pada Rayon Kuala Enok Kabupaten Indragiri Hilir, Universitas Muhammadiyah Sumatra Barat,Padang. 
[5] Suarga, (2012), Algoritma dan Pemrograman, Andi, Yogyakarta.

[6] Sulistyasningtyas, Ike Devi., (2004), Pemberitaan Di Media Massa Sebagai Pembentuk Reputasi Organisasi, Universitas Atma Jaya, Yogyakarta.

[7] Sutabri, Tata, (2012), Analisis Sistem Informasi, Andi, Yogyakarta. 